\title{
Overwinter mortality of young-of-the-year Ezo abalone in relation to seawater temperature on the North Pacific coast of Japan
}

\author{
Hideki Takami ${ }^{1, *}$, Takahiro Saido ${ }^{2}$, Takashi Endo ${ }^{2}$, Tadakatsu Noro ${ }^{3}$, \\ Tatsuya Musashi ${ }^{3}$, Tomohiko Kawamura ${ }^{4}$ \\ ${ }^{1}$ Tohoku National Fisheries Research Institute, Shinhama, Shiogama, Miyagi 985-0001, Japan \\ ${ }^{2}$ Ofunato Regional Development Bureau Department of Fisheries, Inokawa, Ofunato, Iwate 022-8502, Japan \\ ${ }^{3}$ Iwate Prefectural Fisheries Technology Center, Heita, Kamaishi, Iwate 026-0001, Japan \\ ${ }^{4}$ Ocean Research Institute, The University of Tokyo, Minamidai, Nakano, Tokyo 164-8639, Japan
}

\begin{abstract}
The Ezo abalone Haliotis discus hannai is the only species of abalone inhabiting the coastal waters affected by the cold Oyashio current in the Pacific waters of northern Honshu, Japan. Overwinter mortality of young-of-the-year (YOY) Ezo abalone was examined for 2000, 2001, and 2003 to 2006 year classes in Kadonohama Bay, northern Japan, to test the hypothesis that winter seawater temperature controls recruitment fluctuation of this northernmost abalone and regulates their distribution limit. Eggs of Ezo abalone hatch between late summer and mid-autumn, and grow to a size of 2 to $8 \mathrm{~mm}$ in shell length by winter. Overwinter mortality rates varied among years (range: 0 to $97.4 \%$ ), and there was a strong negative relationship between the instantaneous mortality rate and the winter temperature. High mortalities of YOY abalone were observed in February 2001 and March 2006 , respectively. In both cases, the Oyashio current extended south to the study area, and the mean temperature fell to below $5^{\circ} \mathrm{C}$. High mortalities were not observed in the other years when the minimum temperatures were higher than $6^{\circ} \mathrm{C}$, as the Oyashio current did not extend to the study area. The differences in shell length between early winter and post-winter suggest that the low temperature tolerance of YOY abalone may be size-dependent. Although not conclusive, the winter seawater temperature is an important factor affecting the survival of YOY and is the principal factor for the variation in the recruitment of Ezo abalone and the limit of their northward distribution.
\end{abstract}

KEY WORDS: Winter mortality $\cdot$ Temperature tolerance $\cdot$ Abalone $\cdot$ Haliotis discus hannai $\cdot$ Juvenile Recruitment

\section{INTRODUCTION}

The survival and growth of marine invertebrates at their early life stages are considered to be important factors affecting population dynamics through the process of recruitment (reviewed by Gosselin \& Qian 1997). Because of a greater surface area to body volume ratio (Vermeij 1972), younger individuals with smaller body sizes are generally more susceptible to thermal stresses (Gosselin \& Chia 1995, Gosselin \& Qian 1997) and thus may be more intensively affected by low seawater temperature than older individuals with larger sizes (Strand \& Brynjeldsen 2003). Overwinter mortality during early life stages is a potentially important factor in population dynamics, especially for geographically marginal populations of benthic marine invertebrates (e.g. Dekker \& Beukema 1993).

About 10 species of abalone inhabit Japanese coastal waters. The Ezo abalone Haliotis discus hannai is the only abalone species found in waters affected by the cold Oyashio current (Ino 1952) and forms the northern limit of the abalone distribution along coastal Pacific 
waters (Geiger 1999). The Ezo abalone is also among the most economically valuable and important commercial fisheries resources in Japan. The annual catch of this species has declined from a maximum of about $3200 \mathrm{t}$ in 1969 to the current levels of around $1000 \mathrm{t}$. Despite the annual release of millions of artificially produced abalone seed for stock enhancement, abalone resources have not increased for many years.

The main spawning season of the Ezo abalone is from late summer to mid-autumn. Veliger larvae settle onto boulders or bedrock covered with crustose coralline algae (CCA) and metamorphose as postlarvae with initial shell lengths (SL) of $\sim 0.28 \mathrm{~mm}$. They grow for at least several months on CCA (Saito 1981, Sasaki \& Shepherd 1995, 2001) to become early juveniles of $\sim 2$ to $8 \mathrm{~mm}$ SL by their first winter. The distribution of Ezo abalone has been thought to be limited by low water temperatures (Saito 1979). In its northern range boundary on the Pacific coast, annual variation in the recruitment of Ezo abalone has been suggested to correlate with the water temperature in winter (Saido 2002). The abundances of age-1 juveniles examined in autumn tended to decrease when juveniles were exposed to low temperature seawater during their first winter (Saido 2002). However, this year-toyear variation may include variation in their subsequent mortality during spring and summer. Fluctuations in the larval settlement intensity and subsequent survival before winter also mask the correlation between the degree of overwinter mortality and the abundance of age- 1 abalone in autumn. The effect of the winter water temperature on the survival of youngof-the-year (YOY) abalone should be directly examined to elucidate the importance of overwinter mortality on population dynamics. However, the assessment of newly settled abalone has been problematic because field sampling of post-larvae and early juveniles of several mm SL has previously been limited (Saito 1981, Sasaki \& Shepherd 1995, 2001). To our knowledge, no published data are available on natural mortality during the early juvenile stages of Ezo abalone.

We hypothesized that seawater temperature during winter is the principal factor controlling recruitment fluctuation of this northernmost abalone and regulating its distribution limit. For the present study, we found a site where YOY Ezo abalone can be readily and consistently observed in relatively high densities in Kadonohama Bay, Iwate Prefecture. Surveys examining the abundance of YOY individuals in early winter and post-winter from 2000 to 2007 were carried out at this site in order to investigate the relationship between winter water temperature and the overwinter mortality of YOY abalone. We discuss the possible influence of global climate change on long-term fluctuations in the Ezo abalone stock and the degree of southward intrusion of the cold Oyashio current on their northern limit of distribution.

\section{MATERIALS AND METHODS}

Sampling site. Abalone were sampled in the rocky shore area at 6 to $12 \mathrm{~m}$ water depth in Kadonohama Bay, Iwate Prefecture, Japan ( $38^{\circ} 59.0^{\prime} \mathrm{N}, 141^{\circ} 44.4^{\prime} \mathrm{E}$, Fig. 1). The bottom was composed of irregularly shaped boulders (ca. 20 to $80 \mathrm{~cm}$ in diameter) resting on the bedrock. CCA were dominant on these boulders and bedrock.

Measuring larval settlement intensity. To measure the larval settlement intensity of the 2000 year class, pre-grazed plates (Kawamura et al. 2005) were prepared as larval collectors. The pre-grazed plate method is effective to induce rapid and complete metamorphosis of larval abalone, and such settlement plates are used in many Japanese hatcheries (Seki

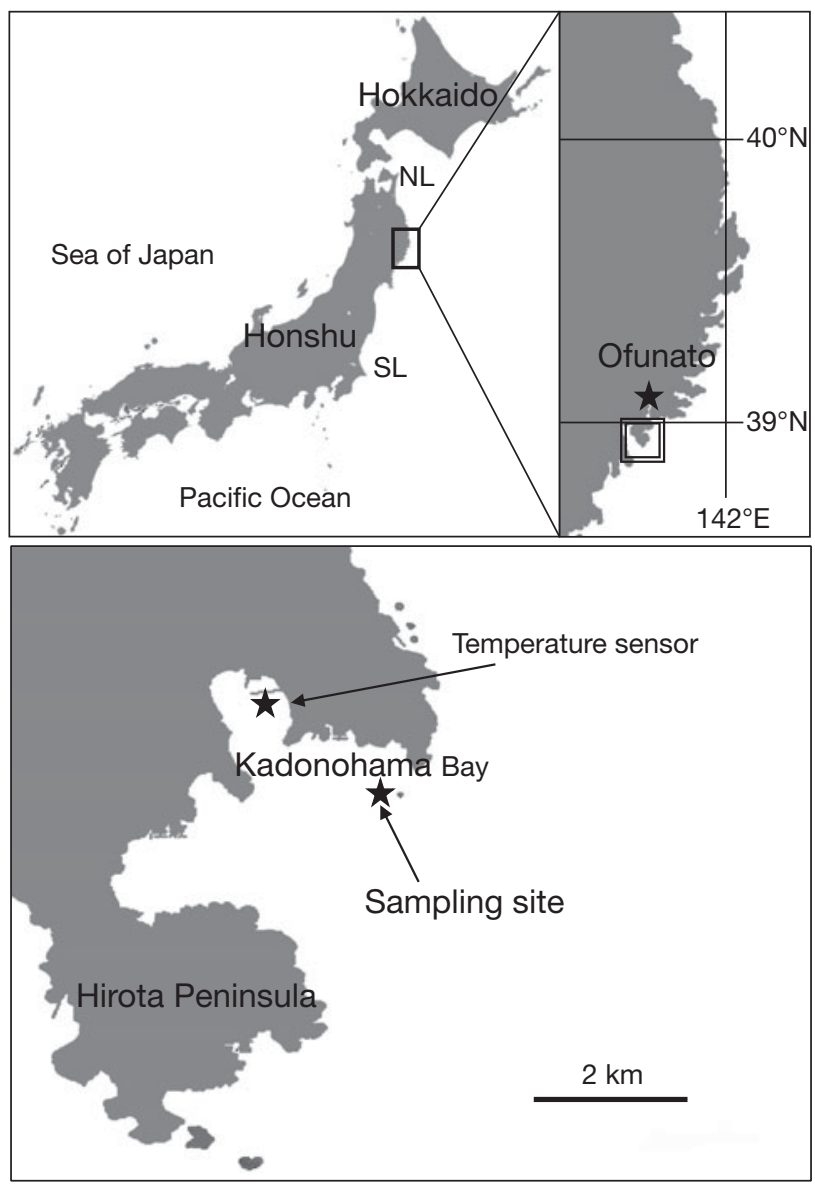

Fig. 1. Haliotis discus hannai. Sampling sites at which the density of young-of-the-year abalone was surveyed and the site at which the temperature sensor was deployed. NL and SL: northern and southern limit, respectively, of the distribution of $H$. discus hannai along the Pacific coast of Japan 
1980) and as larval collectors in the field (Nash et al. 1995). Transparent plastic plates $(30 \times 30 \mathrm{~cm})$ were submerged in an open-air tank supplied with sand-filtered running seawater for $2 \mathrm{wk}$ to allow the development of naturally occurring microalgal films. The plates were then transferred to another aerated tank supplied with $20 \mu \mathrm{m}$ filtered running seawater, and 30 to 50 juvenile Haliotis discus hannai (20 to $30 \mathrm{~mm}$ SL) per plate were added to graze the microalgae on the plates for several weeks. The grazing pressures by the juvenile abalone produced biofilms dominated by the benthic diatoms Cocconeis spp. and the green alga Ulvella lens. The combination of cues from abalone trail mucus and biofilm remnants is highly effective at inducing settlement, with metamorphosis often exceeding $90 \%$ for H. discus hannai (Seki \& Kan-no 1981, Takami et al. 1997). These pre-grazed plates were then placed in the study area from late July to mid-October 2000. Three plates were attached to a buoyed line, with approximately $1 \mathrm{~m}$ between each plate, at a depth of 4 to $6 \mathrm{~m}$, and the bottom plate was $3 \mathrm{~m}$ from the anchor. One larval collector, composed of 3 pre-grazed plates, was used at the study site. Plates were collected and replaced at approximately $2 \mathrm{wk}$ intervals. The collected plates were transported in sealed plastic bags to the laboratory for sorting. After immersion in 5\% seawater formalin, the plates were gently brushed with a soft brush to collect the attached larval and post-larval abalone. All abalone individuals on the plates were counted, and SL was measured to the nearest $10 \mu \mathrm{m}$ using a video camera system with an image analyzer connected to an inverted microscope.

Recruitment surveys. For the 2000 year class, surveys of YOY abalone were carried out by SCUBA diving at monthly intervals from December 2000 to March 2001. Divers haphazardly placed $2 \times 2$ m quadrats ( $\mathrm{n}=4$ to 5 ) on the bedrock, and all abalone in the quadrats were collected by visual searching. The locations of all quadrats were recorded by underwater photography for each survey to avoid repeat sampling. We searched for YOY abalone in every crevice by overturning boulders and removing large epibiota. YOY usually occurred on exposed surfaces of CCA and green microalgae often attached to their shell surfaces, so they were easily distinguishable (Fig. 2). Individuals were carefully removed from CCA surfaces and transferred to a sampling bottle with fine tweezers. To test whether winter mortality is size-dependent, the size distribution of YOY from early winter and post-winter was compared. The SLs of the collected abalone were measured to the nearest $0.1 \mathrm{~mm}$ using a video camera system with an image analyzer connected to a dissecting microscope in the laboratory.

For the 2001 and 2003 to 2006 year classes, surveys of YOY were carried out in early winter (December or

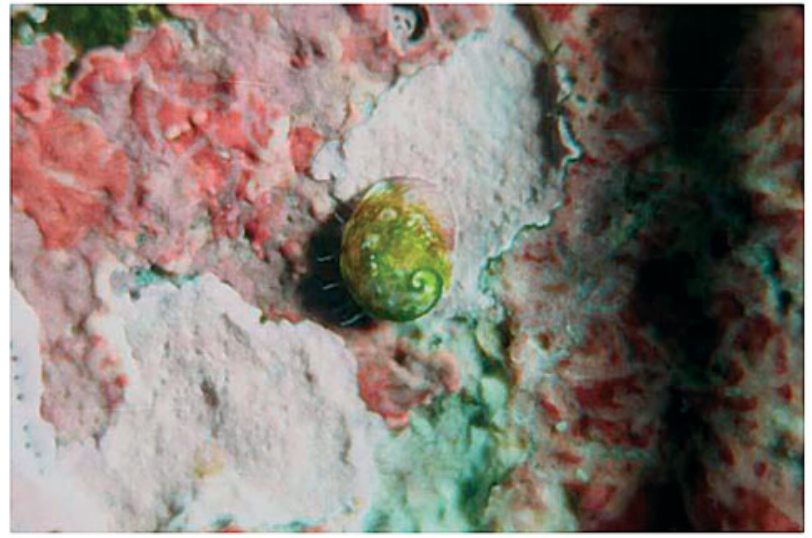

Fig. 2. Haliotis discus hannai. Underwater photo of a young-ofthe-year abalone ( $5 \mathrm{~mm}$ shell length) inhabiting the surface of crustose coralline algae. Green microalgae are attached to the shell surface. Photo: Takahiro Saido

January) and post-winter (February, March, or June) using $2 \times 2$ m quadrats ( $\mathrm{n}=6$ to 11 ) as described above. We were unable to conduct sufficient recruitment surveys in post-winter of 2003 due to continuous rough sea conditions at the sampling site.

Temperature monitoring. The changes in seawater temperatures were recorded at hourly intervals with a battery powered sensor (Optic StowAway Temp, Onset Computer) throughout the winter. The sensor was deployed at a depth of $5 \mathrm{~m}$ in an area allowing some degree of protection from waves, approximately $2 \mathrm{~km}$ from the sampling site in Kadonohama Bay (385․ 59 ' N, $141^{\circ} 43.2^{\prime}$ E, Fig. 1).

The surface water temperature maps around the sampling site provided by the Tohoku National Fisheries Research Institute, Fisheries Research Agency (http://tnfri.fra.affrc.go.jp/kaiyo/temp/temp.html) were used to evaluate winter oceanographic conditions on a large scale, such as changes in the extent of the intrusion of the cold current.

Data analyses. The average density of YOY (ind. $\mathrm{m}^{-2}$ ) derived from quadrat data was calculated for each sampling date. The instantaneous mortality rate $(M)$ of abalone during each winter was calculated using the equation

$$
M=\ln \left(D_{0} / D_{t}\right) /-t
$$

where $t$ is the specific time interval in days; $D_{t}$ is the density of abalone sampled in post-winter after a specific time interval $(t)$; and $D_{0}$ is the density of abalone sampled in early winter. Comparison of the density of abalone between early and post-winter is based on the assumptions that samples are representative of the population, and that there is no migration out of the study area and that no or minimal growth occurs during the period. 
Table 1. Haliotis discus hannai. Total number, mean shell length $\left(\mathrm{SL}, \mu \mathrm{m}, \pm \mathrm{SE}\right.$ ), and mean density (ind. $\mathrm{m}^{-2}, \pm \mathrm{SE}, \mathrm{n}=3$ plates) of post-larvae attached to the larval collectors (composed of three $30 \times 30 \mathrm{~cm}$ settlement plates) on each sampling date in 2000

\begin{tabular}{|lrcc|}
\hline Date & Total & SL & Density \\
\hline 10 August ${ }^{\mathrm{a}}$ & 15 & $480 \pm 3.7$ & $37 \pm 30.6$ \\
23 August & 31 & $457 \pm 2.1$ & $78 \pm 11.0$ \\
7 September & 15 & $665 \pm 6.0$ & $37 \pm 8.8$ \\
21 September & 68 & $289 \pm 0.7$ & $171 \pm 54.7$ \\
5 October & 443 & $848 \pm 0.6$ & $1118 \pm 273.8$ \\
19 October & 4 & $895 \pm 4.0$ & $10 \pm 2.5$ \\
\multicolumn{4}{l}{ a Collector was deployed on 28 July } \\
\hline
\end{tabular}

Density and SL of YOY in early winter and post-winter for each year class were compared by a Wilcoxon rank sum test, as the data were non-normally distributed.

\section{RESULTS}

Larval settlement intensity of the 2000 year class. Although small-scale larval settlements were observed from early August, most of the post-larvae were collected on 21 September and 5 October 2000 from the pre-grazed plates (Table 1). As the larval SL of Ezo abalone is ca. $280 \mu \mathrm{m}$ (Hayashi 1983), abalone collected on 21 September $(289 \pm 0.7 \mu \mathrm{m})$ were assumed to be newly metamorphosed individuals. The mean SL of post-larvae collected on 5 October was $848.4 \pm 0.6 \mu \mathrm{m}$, which apparently indicates a single cohort (Table 1).

The mean growth rate $\left(40 \mu \mathrm{m} \mathrm{d}^{-1}\right)$ and instantaneous mortality rate $\left(0.0322 \mathrm{~d}^{-1}\right)$ on the pre-grazed plates suspended at the sampling site were obtained from a preliminary experiment (T. Saido et al. unpubl. data) in which growth and survival rates in the field were estimated by using plates with artificially settled newly metamorphosed abalone of a known number and size. The date on which larvae settled and the initial density of newly metamorphosed individuals on the plates were tentatively back-calculated using the above constants. The larval SL of $280 \mu \mathrm{m}$ for Haliotis discus hannai (Hayashi 1983) was used for the settlement size. The back-calculation showed that, in 2000, a single large peak of larval settlement occurred around 21 September (Fig. 3).

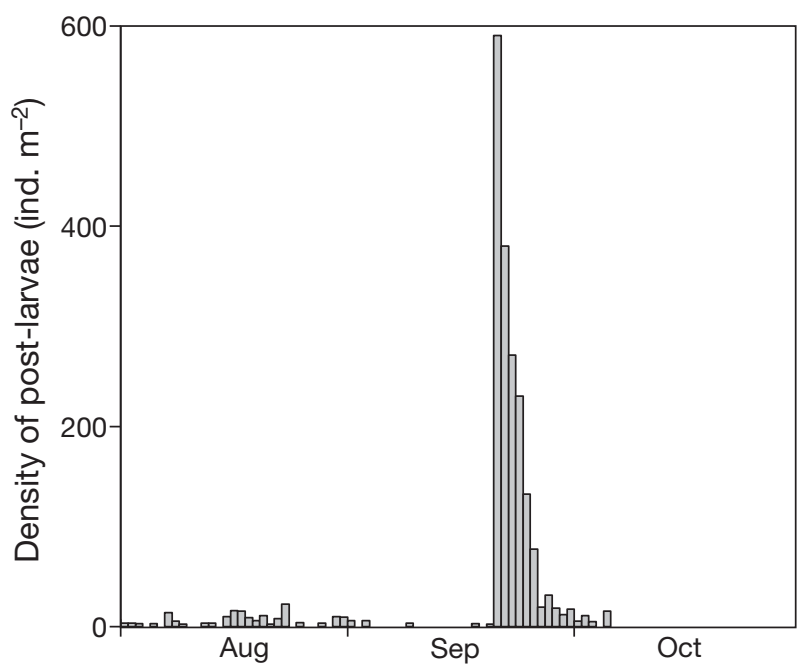

Fig. 3. Haliotis discus hannai. Larval settlement intensity of the 2000 year class during the spawning season. The larval settlement date and the initial density of settlers were estimated by the regular recovery (at ca. 2 wk intervals) of larval collectors deployed at the sampling site at depths of 4 to $6 \mathrm{~m}$

Densities of each year class. The results of sequential surveys of abalone density for each year class are given in Table 2. In the 2000 year class, low survival of YOY was observed during winter. On 28 December 2000, YOY were collected as a single cohort. Considering the results of larval settlement monitoring, this cohort mainly originated from the larvae recorded in

Table 2. Haliotis discus hannai. Mean shell length (mm, $\pm \mathrm{SE})$, total number, and mean density (ind. $\mathrm{m}^{-2}, \pm \mathrm{SE}$ ) of young-of-the-year juveniles sampled by $2 \times 2 \mathrm{~m}$ quadrats in each year class on each sampling date

\begin{tabular}{|c|c|c|c|c|c|}
\hline Year class & Date & Shell length & Total & Density & $\begin{array}{l}\text { No. of } \\
\text { quadrats }\end{array}$ \\
\hline \multirow[t]{4}{*}{2000} & 28 Dec 2000 & $3.3 \pm 0.12$ & 46 & $2.30 \pm 1.28$ & 5 \\
\hline & $23 \operatorname{Jan} 2001^{\mathrm{a}}$ & $3.9 \pm 0.17$ & 30 & $1.50 \pm 0.69$ & 5 \\
\hline & 23 Feb 2001 & - & 0 & 0 & 4 \\
\hline & $22 \operatorname{Mar} 2001^{a}$ & 7.6 & 1 & 0.06 & 5 \\
\hline \multirow[t]{2}{*}{2001} & 26 Dec 2001 & $3.4 \pm 0.37$ & 8 & $0.18 \pm 0.10$ & 11 \\
\hline & 25 Mar 2002 & $3.3 \pm 0.32$ & 3 & $0.13 \pm 0.08$ & 6 \\
\hline \multirow[t]{2}{*}{2003} & 11 Dec 2003 & $2.5 \pm 0.10$ & 43 & $1.19 \pm 0.31$ & 9 \\
\hline & 20 Feb 2004 & $3.5 \pm 0.11$ & 71 & $1.97 \pm 0.81$ & 9 \\
\hline \multirow[t]{2}{*}{2004} & 27 Dec 2004 & $3.0 \pm 0.10$ & 114 & $4.75 \pm 0.96$ & 6 \\
\hline & 7 Jun 2005 & $4.7 \pm 0.75$ & 5 & $0.21 \pm 0.11$ & 6 \\
\hline \multirow[t]{2}{*}{2005} & 20 Jan 2006 & $2.8 \pm 0.12$ & 55 & $2.29 \pm 0.53$ & 6 \\
\hline & 16 Mar 2006 & $4.7 \pm 0.50$ & 12 & $0.50 \pm 0.13$ & 6 \\
\hline \multirow[t]{2}{*}{2006} & 17 Jan 2007 & $3.4 \pm 0.37$ & 20 & $0.63 \pm 0.21$ & 8 \\
\hline & 9 Mar 2007 & $3.2 \pm 0.31$ & 11 & $0.45 \pm 0.18$ & 6 \\
\hline
\end{tabular}



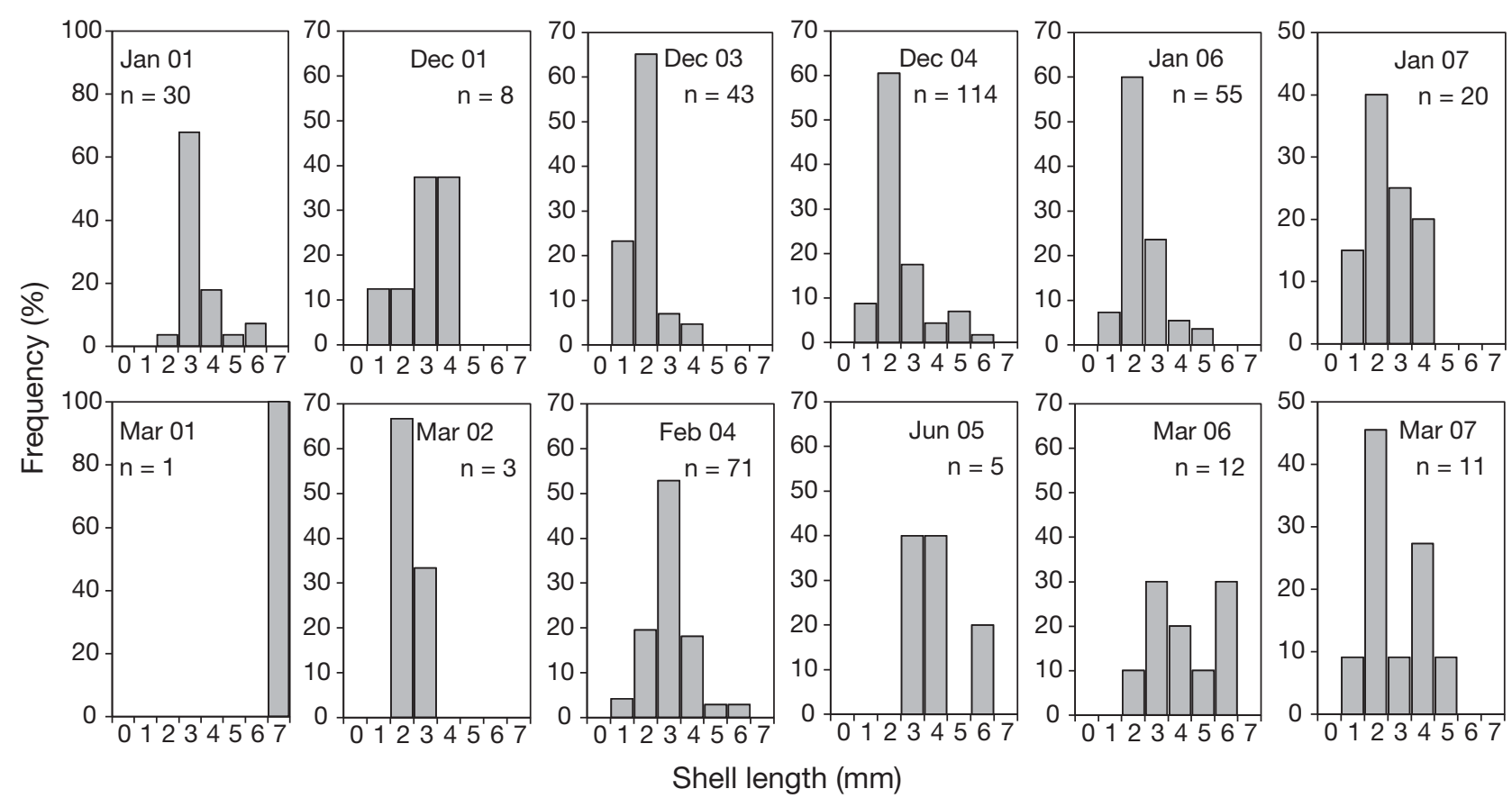

Fig. 4. Haliotis discus hannai. Comparison of shell length distributions of young-of-the-year juveniles between early winter (top row) and post-winter (bottom row)

late September. Although this cohort was still observed on 23 January 2001, no individuals of this cohort were observed on 23 February, and only a single juvenile was collected on 22 March.

We found no significant differences in the YOY densities between early winter and post-winter in 2001, 2003, and 2006 year classes (Wilcoxon rank sum test, $\mathrm{p}>0.6)$. In contrast, YOY densities in post-winter of 2004 and 2005 year classes were significantly lower than those in early winter (Wilcoxon rank sum test, $\mathrm{p}<$ 0.01).

Difference in SL composition between early and post-winter. The SL composition of collected abalone of each year class was compared between early winter and post-winter (Fig. 4). The only juvenile of the 2000 year class collected in post-winter (March 2001) was much larger than juveniles sampled in early winter (January 2001). In the 2001 and 2006 year classes, we found no significant differences in SL of YOY between early winter and post-winter (Wilcoxon rank sum test, p > 0.2). In contrast, SL of 2003, 2004, and 2005 year classes in post-winter were significantly larger than those in early winter (Wilcoxon rank sum test, p < 0.01).

Changes in seawater temperature. The changes in seawater temperature near the sampling site during winter are shown in Fig. 5. The water temperatures from late February to March in 2001 and 2006 were lower than those in the other years. In 2001, the tem- perature sharply dropped within $4 \mathrm{~d}$ from $8.0^{\circ} \mathrm{C}$ on 31 January to $5.2^{\circ} \mathrm{C}$ on 4 February, and the minimum temperature of $4.2^{\circ} \mathrm{C}$ was recorded on 15 February. In 2006, a pronounced decrease was also recorded within $2 \mathrm{wk}$ from $7.3^{\circ} \mathrm{C}$ on 30 January to $4.9^{\circ} \mathrm{C}$ on 12 February, and the minimum temperature of $4.6^{\circ} \mathrm{C}$ was recorded on $15 \mathrm{March}$. The minimum winter temperatures in the other years ranged between 5.8 and $7.9^{\circ} \mathrm{C}$.

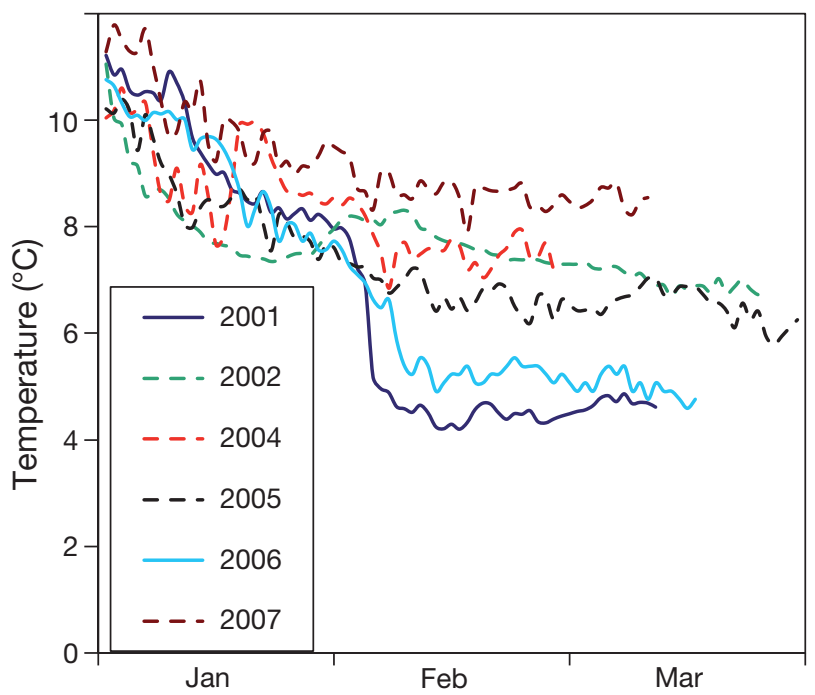

Fig. 5. Changes in water temperatures in Kadonohama Bay during the winter 
The Oyashio cold current flows offshore of the North Pacific coast of Japan, and the degree of southward penetration of the Oyashio front in winter varies between years (Fig. 6). Surface water temperature maps around the sampling site in February and March of 2001 showed that the Oyashio front reached the coastal area, and the water temperature around the sampling site was less than $5^{\circ} \mathrm{C}$ (light to dark blue area, Fig. 6). In February and March of 2006, the low surface temperature $\left(4\right.$ to $\left.5^{\circ} \mathrm{C}\right)$ front also reached the sampling site. In the other years, in contrast, e.g. in 2007, the Oyashio front was farther north and east of the study area, and the sampling site was surrounded by relatively warm waters $\left(>5^{\circ} \mathrm{C}\right.$, yellow to light green area, Fig. 6).

Relationship between abalone mortality and water temperature. The mortality rates of YOY differed markedly among years and ranged from 0 to $97.4 \%$ during winter (Table 2). The relationship between the instantaneous mortality rate and winter seawater tem- perature is shown in Fig. 7. Here, the winter temperature indicates the minimum moving mean temperature for 19 d observed between field surveys of abalone density in each winter, because exposure to low temperatures $\left(<5^{\circ} \mathrm{C}\right)$ for ca. $19 \mathrm{~d}$ negatively affects survival of YOY (see 'Discussion'). The mortality rate of YOY observed between December 2004 and June 2005 was not plotted, as it may have included mortalities in spring and early summer. The instantaneous mortality rate of YOY and the winter temperature had an inverse correlation.

\section{DISCUSSION}

\section{Effect of winter temperature on mortality}

Our results indicate that winter seawater temperature is the principal factor controlling the recruitment intensity of YOY Ezo abalone at Kadonohama Bay,
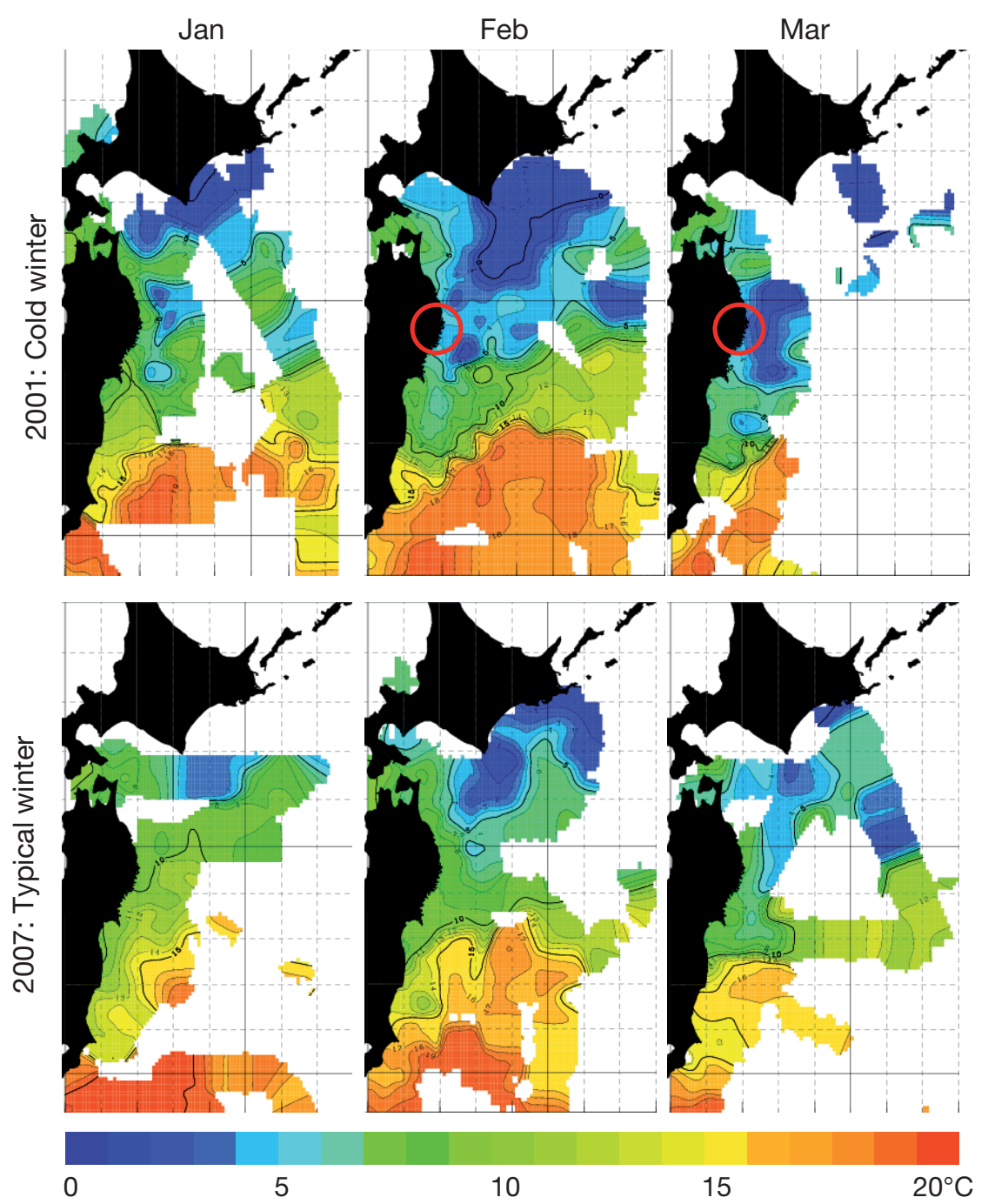

Fig. 6. Sea surface temperatures along the Pacific coast of northern Japan from January to March of 2001 and 2007 provided by the Tohoku National Fisheries Research Institute (http://tnfri.fra.affrc.go.jp/kaiyo/ temp/temp.html). Red circles in February and March 2001 indicate where the extremely low temperature seawater derived from the Oyashio current reached the coastal area, including the sampling site of young-of-the year Haliotis discus hannai 
North Pacific coast of Honshu, Japan. We found clear evidence showing that sporadic low temperatures led to low survival of YOY, particularly in January and February 2001. Large-scale spawning of Ezo abalone is often induced by typhoons or heavy storm events (Sasaki \& Shepherd 1995). The only large peak of larval settlement in 2000 that occurred around 21 September (Fig. 3) probably originated from the largescale spawning induced by the typhoon 'Sonamu,' which passed the study area between 17 and 18 September. Individuals of this cohort grew to more than $3 \mathrm{~mm}$ SL by winter and showed relatively high survival from 28 December 2000 to 22 January 2001. However, between 22 January and 23 February, the density of this cohort dramatically decreased (Table 2). During this period, the battery-powered sensor deployed near the sampling site recorded a sharp decrease in temperature within $4 \mathrm{~d}$, which dropped from $8.0^{\circ} \mathrm{C}$ on $31 \mathrm{Jan}-$ uary to $5.2^{\circ} \mathrm{C}$ on 4 February and then fluctuated between 4.2 and $5.0^{\circ} \mathrm{C}$ until 25 February (Fig. 3). This suggests that the exposure to temperatures below $5.0^{\circ} \mathrm{C}$, lasting for ca. $19 \mathrm{~d}$ (4 to 23 February), had a negative effect on the survival of YOY Ezo abalone.

Similarly, the low survival of YOY during the winter of 2006 can be explained by the extremely low seawater temperature $\left(<5.0^{\circ} \mathrm{C}\right)$ between January and February 2006. The mortality rate during winter of 2005 was also relatively high. However, this may have included mortalities in spring and early summer because the post-winter survey was conducted in June 2005. In addition, juveniles may become cryptic by June, and this could have decreased the search efficiency of the summer survey. High mortalities were not observed in

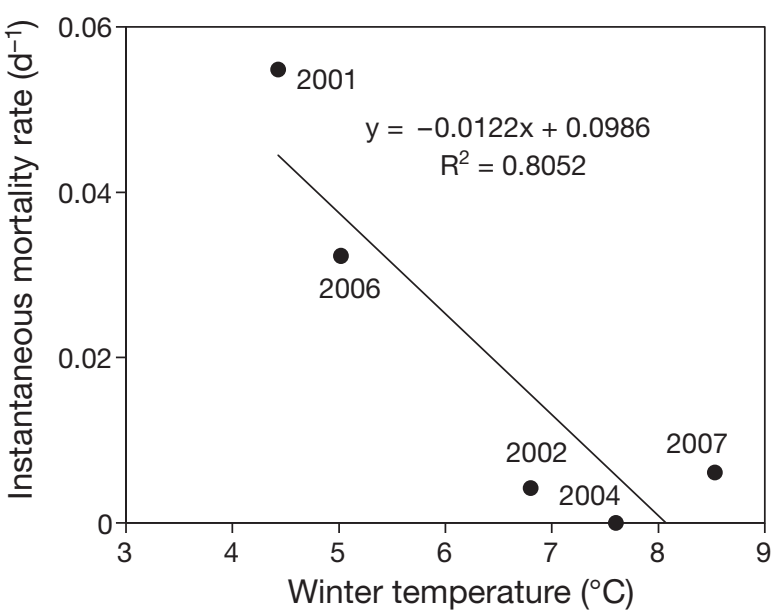

Fig. 7. Haliotis discus hannai. Relationship between seawater temperature and instantaneous mortality rate of young-ofthe-year juveniles during their first winter. The seawater temperature indicates the minimum moving mean of temperature for $18 \mathrm{~d}$ observed during each winter. The numbers indicate survey years the other winters, which experienced minimum sea water temperatures higher than $6^{\circ} \mathrm{C}$ (Fig. 7).

Minimum temperatures $\left(4\right.$ to $5^{\circ} \mathrm{C}$ ) recorded in 2001 and 2006 at our study site may have indirectly affected the mortality of YOY Ezo abalone, because YOY potentially are tolerant of seawater temperatures below 1 to $3^{\circ} \mathrm{C}$ (Kan-no \& Kikuchi 1962, Saito 1981). Low seawater temperatures likely reduce the pedal adhesive strength to substrata in young juveniles (H. Yamaguchi \& N. Inoguchi unpubl. data). This, in turn, may increase their vulnerability to predators and may also increase the probability of dislodgement from suitable habitats by the seawater turbulence. When we conducted an additional survey at the sampling site in May 2006, after high winter mortality was observed, a dense patch of YOY abalone (maximum: 3.25 ind. $\mathrm{m}^{-2}$, mean \pm SE: $0.71 \pm 0.52$ ind. $\mathrm{m}^{-2}, \mathrm{n}=6$ quadrats) was detected. We speculate that these juveniles may have survived by inhabiting refuges from the effects of wave action and/or predators.

\section{Size-dependent mortality}

Our results indicate that the low temperature tolerance of YOY Ezo abalone in their natural habitat may be sizedependent. This could be attributed to the greater surface area to volume ratio, the inferior ability to reduce energy consumption under conditions of thermal stress, and incompletely developed protective adaptations in smaller individuals (e.g. Hunt \& Scheibling 1997). The only juvenile found in post-winter of 2001 was much larger than the juveniles collected in early winter. The mean SL of YOY in post-winter of 2006 was significantly larger than that in early winter (Fig. 4).

The comparison of early winter and post-winter juvenile size to identify size-specific mortality patterns is based on the assumptions that samples are representative of the population, the population is resident and not migratory, and no growth occurs during winter (Hales \& Able 2001). Since YOY abalone occurred at high densities in a limited area, the samples of this study were apparently not biased, and the same population was surveyed between early winter and postwinter. Although individuals collected in post-winter of 2001 and 2006 were larger than those in early winter, growth was unlikely to have occurred between the 2 surveys, because a laboratory experiment showed that early juvenile Ezo abalone could not grow when the water temperature was below $7.6^{\circ} \mathrm{C}$ (Uki et al. 1981), and seawater temperatures during these winters were predominantly below $6^{\circ} \mathrm{C}$ (Fig. 5).

YOY of the 2003 year class probably grew during the relatively warmer winter of 2004. In YOY of the 2004 year class, juveniles probably grew during spring and 
early summer; therefore, the mean SL was significantly larger in post-winter than in early winter. The method to calculate mortality rate does not take into account the search efficiency of the divers when surveying $2 \times$ $2 \mathrm{~m}$ quadrats. Although growth during the winter period is considered to be minimal, if some growth of juveniles occurred between the first and the second survey, the efficiency of finding smaller juveniles in the first survey may have been lower than finding slightly larger juveniles in the second survey. However, this would make the estimates of winter mortality conservative.

The size-dependent mortality implies that growing larger before winter is important for YOY abalone to survive the winter, especially when water temperatures are low. The food availability in post-larval and juvenile habitats, such as density and species composition of benthic diatoms and juvenile macroalgae on CCA, influences post-larval and juvenile growth rates (Kawamura et al. 1998). In addition, individuals that hatched earlier in the spawning season have increased chances of growing larger before winter. The timing of typhoons and storms that impact abalone habitats and induce synchronous spawning may affect recruitment success. Some small-scale spawning occurred from early August to mid September (Fig. 3) in 2000 prior to the large-scale spawning induced by the typhoon 'Sonamu,' and individuals from these earlier spawning events may have grown larger before winter than those from the later large-scale spawning. However, there is a possibility that larvae and post-larvae hatching early in the spawning season are at a disadvantage in terms of survival compared to those hatching later. This is because Ezo abalone have the capacity for multiple ovulations during a spawning season (Fukazawa et al. 2007), and the lipid and protein contents of eggs, which are related to larval and post-larval survival, are lower in eggs produced early in the spawning season than in those produced in the middle of the spawning season (Fukazawa et al. 2005). However, as early spawned eggs will have more potential to grow to larger sizes prior to the onset of winter and thus be better adapted to survive low temperatures, these early spawnings of low quality eggs may be an adaptation to variable winter conditions.

The underlying mechanisms causing increased mortality of YOY abalone at lower than normal winter temperatures were not clearly elucidated in this study. An increased vulnerability to predators and/or seawater turbulence can be considered an important indirect factor in the field. Winter mortality caused by these factors may be size-dependent. Further investigation is needed on the effects of low seawater temperature on physiological stress and reduction of pedal adhesive strength, in addition to the size-dependent tolerance.

\section{Impact of cold water movement on abalone population dynamics}

In the last $10 \mathrm{yr}$, natural recruitment of Ezo abalone has markedly increased, which has been reflected by the increase in catch (Fig. 8). Relatively high seawater temperatures in winter since the early 1990s are suggested to be a main factor increasing the natural recruitment of Ezo abalone (Saido 2002). However, even in recent years, unusually low seawater temperatures in winter, such as in 2001, caused high mortalities in YOY Ezo abalone. Since the age at first catch of Ezo abalone is 4 to 5 yr (Sasaki 1999), the sharp decline of the commercial catch in 2005 (Fig. 8) can be attributed to recruitment failure of the 2000 year class caused by the low winter water temperature in 2001. This decline in the catch also suggests that the cold winter of 2001 mainly affected the survival of the YOY 2000 year class rather than older year classes, because the catch remained relatively constant between 2001 and 2003.

When the Oyashio front reached our sampling site, water temperatures sharply decreased and YOY abalone experienced high mortalities (Table 2, Figs. 5 to 7). In contrast, the approach of the Oyashio leads to increases in kelp biomass, because the cold and nutrient-rich Oyashio waters facilitate the growth of algae and decrease the grazing pressure of herbivores (Kirihara et al. 2006). After winters with very low water temperatures, the food availability for adult abalone becomes favorable due to flourishing kelp species. This accelerates the gonad maturation of adult abalone (Uki \& Kikuchi 1982), potentially increasing their reproductive output. Hence, the larval settlement intensity may be strong for the year classes after a cold

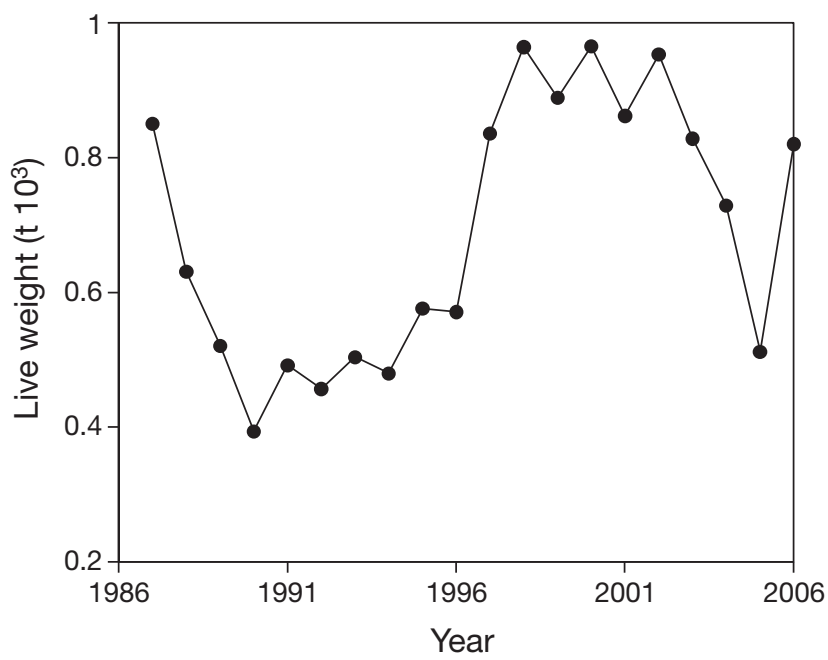

Fig. 8. Haliotis discus hannai. Recent changes in the commercial catch along the Pacific coast of northern Honshu Island, Japan 
winter, although we did not observe higher recruitment for the 2001 and 2006 year classes (Table 2), which occurred after cold winters.

The anomalous southward intrusion of the Oyashio is associated with global changes in the atmospheric circulation. Prior to the occurrence of the strong intrusion of the Oyashio, the southward formation of the Aleutian Low Pressure in mid-winter was commonly observed (Sekine \& Suzuki 1991). A significant negative correlation has been noted between the Aleutian Low Pressure Index (ALPI) and the winter sea surface temperature along the Pacific coast of northern Japan (Nakamura et al. 2005). Furthermore, a significant negative correlation is also observed between the trend of fluctuations in the commercial catch of Ezo abalone and ALPI (Hayakawa et al. 2007), indicating that the abundance of abalone decreases during low temperature regimes. Our results imply that the negative correlation between the fluctuation in the Ezo abalone catch and ALPI can be explained by the change in the survival rate of YOY abalone, which is strongly affected by the water temperature in winter. Since the early 1990s, the recruitment of Ezo abalone in Pacific coastal waters of northern Japan has markedly increased due to the relatively warm winter water temperature in the low ALPI regime, as reflected by the increasing catch, with a delay of several years. However, the increase in catch has not occurred everywhere in the area. The increase in recruitment has been observed only in a few limited areas. It is hypothesized that the natural recruitment has not yet begun to increase in areas with low adult densities (Kawamura \& Takami 2005). Overfishing of abalone broodstocks influences reproductive output, which may hinder the recovery of stocks when the environmental conditions improve sufficiently to allow successful recruitment.

\section{Factors limiting abalone distribution}

The sporadic influx of the Oyashio front leads to recruitment failure of YOY Ezo abalone. The Ezo abalone has the northernmost distribution along the west Pacific coast of Honshu Island (Fig. 1), and its distribution may be limited by cold water from the Oyashio current. The Pacific coast of Hokkaido, the geographically nearest northward coastal area to the distribution limit of Ezo abalone, is constantly surrounded by the cold Oyashio current during winter, as shown in Fig. 6. The results of this study imply that YOY Ezo abalone may frequently fail in overwintering under such severe winter conditions, and this species is unable to establish a population in coastal areas where the Oyashio current predominates during winter.
Ezo abalone are thought to have descended from a once amphipacific species that radiated from California and subsequently became disjunct (Lee \& Vacquier 1995). The pinto abalone Haliotis kamtschatkana is the northernmost species along the eastern coast of the North Pacific. Although no data have been published on overwinter mortality in early life stages of this abalone species, we think that the recruitment process of this counterpart to $H$. discus hannai may also be considerably affected by winter conditions near the northern range boundary.

Acknowledgements. We thank the members of the Iwate Prefectural Fisheries Technology Center for their assistance in the field. We also thank C. Norman for correcting the English grammar and the anonymous referees for their helpful comments. This study was partly supported by a Grant-inAid from the Fisheries Research Agency, Japan.

\section{LITERATURE CITED}

Dekker R, Beukema JJ (1993) Dynamics and growth of a bivalve, Abra tenuis, at the northern edge of its distribution. J Mar Biol Assoc UK 73:497-511

Fukazawa H, Takami H, Kawamura T, Watanabe Y (2005) The effect of egg quality on larval period and postlarval survival of an abalone Haliotis discus hannai. J Shellfish Res 24:1141-1147

Fukazawa H, Kawamura T, Takami H, Watanabe Y (2007) Oogenesis and relevant changes in egg quality of abalone Haliotis discus hannai during a single spawning season. Aquaculture 270:265-275

Geiger DL (1999) A total evidence cladistic analysis of the Haliotidae (Gastropoda: Vetigastropoda). PhD dissertation, University of Southern California, Los Angeles

Gosselin LA, Chia FS (1995) Characterizing temperate rocky shores from the perspective of an early juvenile snail: the main threats to survival of newly hatched Nucella emarginata. Mar Biol 122:625-635

Gosselin LA, Qian PY (1997) Juvenile mortality in benthic marine invertebrates. Mar Ecol Prog Ser 146:265-282

Hales LS Jr, Able KW (2001) Winter mortality, growth and behavior of young-of-the-year of four coastal fishes in New Jersey (USA) waters. Mar Biol 139:45-54

Hayakawa J, Yamakawa T, Aoki I (2007) Long-term fluctuation in the abundance of abalone and top shell in Japan and factors affecting those fluctuations. Bull Jpn Soc Fish Oceanogr 71:96-105 (in Japanese with English abstract)

Hayashi I (1983) Larval shell morphology of some Japanese Haliotids for the identification of their veliger larvae and early juveniles. Venus 42:49-58 (in Japanese with English abstract)

Hunt HL, Scheibling RE (1997) Role of early post-settlement mortality in recruitment of benthic marine invertebrates. Mar Ecol Prog Ser 155:269-301

Ino T (1952) Biological studies on the propagation of Japanese abalone (genus Haliotis). Bull Tokai Reg Fish Res Lab 5: 1-102 (in Japanese with English abstract)

Kan-no H, Kikuchi S (1962) On the rearing of Anadara broughtonii (Schrenk) and Haliotis discus hannai Ino. Bull Mar Biol Stn Asamushi Tohoku Univ 11:71-76

Kawamura T, Takami H (2005) Ecology and recruitment fluctuations of abalone. In: Watanabe Y (ed) Living marine 
resources: How do they fluctuate in the ocean? Tohkai University Press, Tokyo (in Japanese)

Kawamura T, Roberts RD, Takami H (1998) A review of the feeding and growth of postlarval abalone. J Shellfish Res 17:615-625

Kawamura T, Roberts RD, Takami H (2005) Importance of periphyton in abalone culture. In: Azim ME, Verdegem MCJ, van Dam AA, Beveridge MCM (eds) Periphyton. Ecology, exploitation and management. CABI Publishing, Wallingford

Kirihara S, Nakamura T, Kon N, Fujita D, Notoya M (2006) Recent fluctuations in distribution and biomass of cold and warm temperature species of Laminarialean algae at Cape Ohma, northern Honshu, Japan. J Appl Phycol 18:521-527

Lee YH, Vacquier VD (1995) Evolution and systematics in Haliotidae (Mollusca: Gastropoda): inferences from DNA sequences of sperm lysin. Mar Biol 124:267-278

Nakamura A, Kitada S, Hamasaki K, Okouchi H (2005) Catch fluctuation in Haliotis spp. abalones: annual landings of the Ezo abalone Haliotis discus hannai in relation to climate oscillation and stock enhancement programs. Saibai Giken 33:45-54 (in Japanese with English abstract)

Nash WJ, Sanderson JC, Bridley J, Dickson S, Hislop B (1995) Post-larval recruitment of blacklip abalone (Haliotis rubra) on artificial collectors in southern Tasmania. Mar Freshw Res 46:531-538

Saido T (2002) Recent recovery of abalone stock in Iwate Prefecture, Japan. Kaiyo Monthly 34:477-481 (in Japanese)

Saito K (1979) Studies on propagation of Ezo abalone, Haliotis discus hannai Ino-I. Analysis of the relationship between transplantation and catch in Funka Bay coast. Bull Jpn Soc Sci Fish 45:695-704

Saito K (1981) The appearance and growth of 0-year-old Ezo abalone. Bull Jpn Soc Sci Fish 47:1393-1401

Sasaki R (1999) Ecological studies on the recruitment structure in abalone Haliotis discus hannai Ino. PhD disserta-

Editorial responsibility: Antony Underwood, Sydney, New South Wales, Australia tion, Tohoku University, Sendai (in Japanese with English abstract)

Sasaki R, Shepherd SA (1995) Larval dispersal and recruitment of Haliotis discus hannai and Tegula spp. on Miyagi coasts, Japan. Mar Freshw Res 46:519-529

Sasaki R, Shepherd SA (2001) Ecology and post-settlement survival of the Ezo abalone Haliotis discus hannai, on Miyagi coasts, Japan. J Shellfish Res 20:619-626

Seki T (1980) An advanced biological engineering system for abalone seed production. In: Int Symp Coast Pac Mar Life. Western Washington University, Bellingham, WA

Seki T, Kan-no H (1981) Induced settlement of the Japanese abalone, Haliotis discus hannai Ino. Bull Tohoku Reg Fish Res Lab 43:29-36 (in Japanese with English abstract)

Sekine Y, Suzuki Y (1991) Occurrence of anomalous southward intrusion of the Oyashio and the variation in global atmospheric circulation. Umi to Sora 67:11-23 (in Japanese with English abstract)

Strand Ø, Brynjeldsen E (2003) On the relationship between low winter temperatures and mortality of juvenile scallops, Pecten maximus L., cultured in western Norway. Aquacult Res 34:1417-1422

Takami H, Kawamura T, Yamashita Y (1997) Survival and growth rates of post-larval abalone Haliotis discus hannai fed conspecific trail mucus and/or benthic diatom Cocconeis scutellum var. parva. Aquaculture 152:129-138

Uki N, Kikuchi S (1982) Influence of food levels on maturation and spawning of the abalone, Haliotis discus hannai related to effective accumulative temperature. Bull Tohoku Reg Fish Res Lab 45:45-53

Uki N, Grant JF, Kikuchi S (1981) Juvenile growth of the abalone, Haliotis discus hannai, fed certain benthic micro algae related to temperature. Bull Tohoku Reg Fish Res Lab 43:59-64

Vermeij GJ (1972) Intraspecific shore-level size gradients in intertidal mollusks. Ecology 53:693-700

Submitted: December 12, 2007; Accepted: April 29, 2008

Proofs received from author(s): September 4, 2008 